\title{
Correction: Obesity in adolescents with chronic fatigue syndrome: an observational study
}

Norris T, Hawton K, Hamilton-Shield J, et al. Obesity in adolescents with chronic fatigue syndrome: an observational study. Arch Dis Child 2017;102:35-9. doi: 10.1136/ archdischild-2016-311293.

The Editor of the journal has agreed to the request from the authors that the ethics statement should be changed to improve its clarity. The new statement is as follows: 'The CFS/ME patient data used in this study were collected as part of routine clinical practice and anonymised for the National Outcomes Database. Under the Governance Arrangements for Research Ethics Committees (September 2011), ethical review is not required for research limited to the use of previously collected, non-identifiable patient information.'

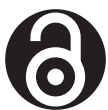

\section{OPEN ACCESS}

Open access This is an open access article distributed in accordance with the Creative Commons Attribution 4.0 Unported (CC BY 4.0) license, which permits others to copy, redistribute, remix, transform and build upon this work for any purpose, provided the original work is properly cited, a link to the licence is given, and indication of whether changes were made. See: https://creativecommons.org/licenses/by/4.0/.

(C) Author(s) (or their employer(s)) 2020. Re-use permitted under CC BY. Published by BMJ.

Arch Dis Child 2020;105:e1. doi:10.1136/archdischild-2016-311293corr1

Check for updates 